\title{
KEWENANGAN BANK INDONESIA DALAM MELAKUKAN FUNGSI PENGAWASAN PADA LEMBAGA KEUANGAN BANK PASCA LAHIRNYA UU NOMOR 21 TAHUN 2011 TENTANG OTORITAS JASA KEUANGAN
}

\author{
AUTHORITY BANK INDONESIA FUNCTION IN DOING IN FINANCIAL INSTITUTIONS BANK \\ SUPERVISION AFTER THE BIRTH OF LAW NUMBER 21 OF 2011 CONCERNING THE FINANCIAL \\ SERVICES AUTHORITY
}

\author{
Dhian Indah A, Dharu Triasih,Agus Syaiful Adib \\ Fakultas Hukum Universitas Semarang
}

\begin{abstract}
ABSTRAK
Pemanfaatan jasa lembaga keuangan semakin meningkat seiring perkembangan teknologi dan informasi dalam kehidupan masyarakat. Pada kesempatan yang bersamaan, kondisi demikian turut serta mendukung upaya peningkatan perekonomian nasional. Salah satu elemen yang berkaitan dengan perekonomian nasional adalah masalah sistem keuangan dan kegiatan industri jasa keuangan yang lain, seperti misalnya lembaga keuangan bank maupun lembaga keuangan non bank. Eksistensi lembaga keuangan dalam mendukung perekonomian nasional adalah merupakan salah satu dampak dari globalisasi dan kemajuan teknologi yang berujung pada kompleksitas sistem keuangan di Indonesia. Kompleksitas yang terjadi perlu diurai sehingga dapat ditemukan solusinya, karena sistem keuangan yang kondusif akan mendukung terciptanya stabilitas perekonomian. Masalah pengawasan perbankan di Indonesia sampai saat ini masih menjadi sorotan, dari kasus BLBI, kredit macet, kasus bank Global, kasus bank Century, yang kesemuanya itu menunjukkan bahwa masih banyak bank yang belum sepenuhnya menjalankan prinsip kehati-hatian dalam kegiatan usahanya dan lemahnya pengawasan perbankan oleh Bank Indonesia. Permasalahan yang kami angkat bagaimana kewenangan BI dalam melakukan fungsi pada lembaga keuangan pasca lahirnya UU Nomor 21 Tahun 2011 tentang Otoritas Jasa Keuangan dan bagaimana independesi OJK dalam melakukan fungsi pengawasan pada lembaga keuangan bank. Metode pendekatan yang digunakan adalah yuridis normatif,dengan mempelajari dan mengkaji azas-azas hukum yang berasal dari bahan-bahan kepustakaan. Spesfikasi penelitian yang digunakan deskriptif analitis. Jenis data yang digunakan adalah data sekunder yang terdiri dari bahan hukum primer, bahan hukum sekunder serta bahan hukum tersier. Data-data tersebut kemudian dianalisis secara kualitatif dan hasilnya akan diuraikan dalam bentuk laporan. Penelitian ini akan mengkaji mengenai kewenangan BI dalam melakukan fungsi pengawasan pada lembaga keuangan Bank pasca lahirnya UU Nomor 21 Tahun 2011 tentang Otoritas Jasa Keuangan, Bank Indonesia memiliki kewenangan, tanggung jawab dan kewajiban secara utuh untuk melakukan pembinaan dan pengawasan terhadap bank dengan menempuh upaya-upaya baik yang bersifat preventif maupun represif. Azas independensi lebih tegas dituangkan dalam penjelasan umum UU OJK yang menyatakan bahwa OJK melaksanakan tugas dan wewenangnya berlandaskan azas independen dalam pengambilan keputusan dan pelaksanaan fungsi, tugas dan wewenang OJK dengan tetap sesuai peraturan perundang-undangan yang berlaku.
\end{abstract}

Kata kunci : Kewenangan , BI, Pengawasan, Otoritas Jasa Keuangan

\begin{abstract}
Utilization of services of financial institutions is increasing with the development of technology and information in society. On the same occasion, this condition participate and support efforts to improve the national economy. One of the elements related to the national economy is the problem of the financial system and the activities of other financial services industry, such as financial institutions banks and nonbank financial institutions. The existence of financial institutions in supporting the national economy is one of the impact of globalization and technological advances that led to the complexity of the financial system in Indonesia. Complexity is happening needs to be parsed so that it can be solved, because the financial system is conducive to support the creation of economic stability. Problem banking supervision in Indonesia is still in the spotlight, from BLBI, bad debts, cases of bank Global, the case of bank Century, all of which indicate
\end{abstract}


that there are still many banks that have not fully follow the principle of prudence in its business activity and weak banking supervision by Bank Indonesia. The problems that we lift how BI authority in performing the functions of financial institutions after the enactment of Law No. 21 Year 2011 on the Financial Services Authority and how the FSA independence in performing supervisory functions in the financial institution. The method used is a normative juridical, by studying and reviewing principles of law derived from the materials library. Specs research is descriptive. Data used is secondary data consists of primary legal materials, secondary law and tertiary legal materials. The data was then analyzed qualitatively and the results will be described in the form of a report. This study will examine the authority of the central bank in performing supervisory functions in the financial institution Bank after the enactment of Law No. 21 Year 2011 on the Financial Services Authority, Bank Indonesia has the authority, responsibility and obligation as a whole to conduct guidance and supervision of banks by taking measures both preventive and repressive. The principle of independence is expressly stated in the explanation of the common law which states that the FSA FSA carrying out the duties and responsibilities based on the principle of independent decision-making and implementation of the functions, duties and powers to the FSA remains the appropriate laws and regulations in force.

Keywords: Authority, BI, Supervision, the Financial Services Authority

\section{PENDAHULUAN}

Di dalam Undang-undang Nomor 7 Tahun 1992, tentang Perbankan yang telah diubah dengan UU Nomor 10 Tahun 1998 (selanjutnya disebut Undang-undang Perbankan) disebutkan bahwa yang dimaksud dengan bank adalah badan usaha menghimpun dana dari masyarakat dalam bentuk simpanan dan menyalurkannya kepada masyarakat dalam rangka meningkatkan taraf hidup rakyat banyak. ${ }^{1}$

Pemanfaatan jasa lembaga keuangan semakin meningkat seiring perkembangan teknologi dan informasi dalam kehidupan masyarakat. Pada kesempatan yang bersamaan, kondisi demikian turut serta mendukung upaya peningkatan perekonomian nasional. Salah satu elemen yang berkaitan dengan perekonomian nasional adalah masalah sistem keuangan dan kegiatan industri jasa keuangan yang lain, seperti misalnya lembaga keuangan bank maupun lembaga keuangan non bank. Eksistensi lembaga keuangan dalam mendukung perekonomian nasional demikian merupakan salah satu dampak dari globalisasi dan kemajuan dan kemajuan teknologi yang berujung pada kompleksitas sistem keuangan di Indonesia. Kompleksitas yang terjadi perlu diurai sehingga dapat ditemukan solusinya, karena sistem keuangan yang kondusif akan mendukung terciptanya stabilitas pertumbuhan perekonomian. Pada kesempatannya, stabilitas pertumbuhan ekonomi akan mendukung pembangunan nasional di segala bidang.

\footnotetext{
${ }^{1}$ Pasal 1 angka 1 Undang-undang Nomor 7 Tahun 1992, tentang Perbankan sebagaimana telah diubah dengan Undang-undang Nomor 10 Tahun 1998.
}

Masalah pengawasan perbankan di Indonesia sampai saat ini masih selalu mendapat sorotan, dari kasus BLBI, kemudian kasus adanya kredit macet dengan jumlah besar di BNI tentang kasus Loan/ Credit fiktif di BNI, kasus Bank Global, kasus Bank Century dan masih banyak kasus-kasus lain, yang kesemuanya itu menunjukkan bahwa masih banyak bank yang belum sepenuhnya menjalankan prinsip kehati-hatian dalam kegiatan usahanya dan lemahnya pengawasan perbankan oleh Bank Indonesia sebuah tantangan dan tanggung jawab yang sangat besar bagi lembaga yang berwenang mengawasi perbankan yang harus segera ditangani dan diupayakan penyelesaiannya.

Mencermati persoalan yang telah diuraikan di atas, maka Pemerintah bersama sama dengan legislatif membentuk peraturan perundangundangan yang bertujuan untuk mengalihkan fungsi pengawasan bank dari Bank Indonesia kepada sebuah lembaga independen yaitu Otoritas Jasa Keuangan, sehingga dibentuk Undang-undang Nomor 21 Tahun 2011 tentang Otoritas Jasa Keuangan (OJK). Apabila dirunut, sejarah OJK bermula sejak diundangkannya Undang-undang Nomor 23 Tahun 1999 sebagaimana diubah dan ditambah dengan Undang-undang Nomor 3 tahun 2004 tentang Bank Indonesia untuk selanjutnya disebut Undang-Undang Bank Indonesia. Dalam Undang-undang tersebut, disebutkan secara tegas bahwa tugas mengawasi bank akan dilakukan oleh lembaga pengawasan sektor jasa keuangan yang independen, dan dibentuk dengan Undangundang. Ketentuan selanjutnya disebutkan dalam Pasal 34 ayat 1 Undang-undang Bank Indonesia bahwa pembentukan lembaga pengawasan akan dilaksanakan selambat-lambatnya 31 Desember 2002. Pernyataan demikian menjadi sebuah landasan yang kuat bagi pembentukkan lembaga 
independen untuk mengawasi sektor jasa keuangan dan selambat-lambatnya pada tanggal yang telah disebutkan yaitu 31 Desember 2002 harus sudah terbentuk. Akan tetapi dalam prosesnya, sampai dengan tahun 2010 OJK belum terbentuk. Sampai kemudian Undang-Undang OJK baru terealisasi pada tahun 2011 dengan disahkannya UndangUndang Nomor 21 Tahun 2011 tentang Otoritas Jasa Keuangan.

Pengalihan pengawasan bank dari Bank Ind onesia ke Otoritas Jasa Keuangan diharapkan akan membawa pengaruh positif dalam aktivitas bisnis perbankan. Keberadaan OJK diharapkan mampu memberikan kemajuan yang mengarah kepada iklim kondusif bagi pengembangan dan pembangunan perbankan di Indonesia. Pengalihan fungsi pengawasan perbankan kepada lembaga independen dalam hal ini OJK dinilai sebagai langkah paling tepat guna mewujudkan tujuan penyehatan dan pengembangan perbankan. Hal demikian berkait dengan fungsi OJK untuk mengawasi perbankan sekaligus pembentukan pengaturan terhadap pelaksanaan kinerja perbankan. Dalam melakukan pengawasan, OJK tetap melakukan koordinasi dengan Bank Indonesia, jadi walaupun sebagian wewenang dari Bank Indonesia telah beralih kepada OJK, masih ada hubungan terintegrasi antara Bank Indonesia dengan OJK yang harus dijelaskan secara rinci supaya tidak ada tumpang tindih antara wewenang Bank Indonesia selaku Bank Sentral dengan OJK sebagai lembaga pengawasan di sektor perbankan.

Persoalan pengawasan perbankan yang dem ikian kompleks dan memerlukan perhatian yang serius menjadi alasan bagi peneliti untuk mengkaji secara mendalam mengenai Kewenangan BI dalam melakukan Fungsi Pengawasan Pada Lembaga Keuangan Bank pasca lahirnya UU Nomor 21 Tahun 2011 tentang Otoritas Jasa Keuangan serta independensi Otoritas Jasa Keuangan dalam pengawasan perbankan di indonesia.

\section{KAJIAN PUSTAKA}

\section{Tinjauan Umum mengenai Bank dan Dasar Hukum Perbankan}

\subsection{Pengertian Bank}

Beberapa pendapat tentang pengertian bank, antara lain :

a. Abdurrachman, mengemukakan perbankan (banking) pada umumnya ialah kegiatankegiatan dalam menjual-belikan mata uang, surat efek dan instrumen-instrumen yang dapat diperdagangkan. Penerimaan deposito, untuk memudahkan penyimpanannya atau untuk mendapatkan bunga, dan/atau pembuatan, pemberian pinjaman-pinjaman dengan atau tanpa barang-barang disimpan. Pembelian, penjualan, penukaran, atau penguasaan atau penahanan alat pembayaran, instrumen yang dapat diperdagangkan, atau benda-benda lainnya yang mempunyai nilai moneter secara langsung sebagai suatu kegiatan yang teratur. ${ }^{2}$

b. O.P.Simorangkir mengemukakan, Bank merupakan salah satu badan usaha lembaga keuangan yang bertujuan memberikan kredit dan jasa-jasa. Adapun pemberian kredit itu dilakukan baik dengan modal sendiri atau dengan dana-dana yang dipercayakan oleh pihak ketiga maupun dengan jalan memperedarkan alat-alat pembayaran baru berupa uang giral. ${ }^{3}$

c. Dalam Pasal 1 angka 1 Undang-undang Nomor 7 Tahun 1992 tentang Perbankan, sebagaimana telah diubah dengan Undangundang Nomor 10 Tahun 1998 (selanjutnya disingkat dengan UUP) dijelaskan : Perbankan adalah segala sesuatu yang menyangkut tentang bank, mencakup kelembagaan, kegiatan usaha, serta cara dan proses dalam melaksanakan kegiatan usahanya, Sedangkan pengertian bank dijelaskan dalam Pasal 1 angka 2 UUP : Bank adalah badan usaha yang menghimpun dana dari masyarakat dalam bentuk simpanan dan menyalurkannya kepada masyarakat dalam bentuk kredit dan/atau bentuk-bentuk lainnya dalam rangka meningkatkan taraf hidup rakyat banyak.

\subsection{Fungsi Perbankan}

Fungsi bank adalah menghimpun dana dari masyarakat dan menyalurkannya kembali kepada masyarakat untuk berbagai tujuan atau sebagai financial intermediary. Secara lebih jelas fungsi bank dapat dijelaskan sebagai berikut: ${ }^{4}$

a. Agent of Trust

Dasar utama kegiatan perbankan adalah trust atau kepercayaan, baik dalam hal penghimpunan dana maupun penyaluran dana. Masyarakat akan mau menitipkan dananya di bank apabila dilandasi oleh unsur kepercayaan.

\footnotetext{
${ }^{2}$ Abdurrachman,Ensiklopedi Ekonomi Keuangan Perdagangan Inggris-Indonesia (Jakarta:Perbanas, 1988), halaman 10. ${ }^{3}$ O.P.Simorangkir, Seluk Beluk Bank Komersial (Jakarta : Perbanas, 1988), halaman 10.

4 H. Malayu S.P Hasibuan, Dasar-dasar Perbankan,( Jakarta: PT. Bumi Aksara, 2006), halaman 6-8
} 
b. Agent of Development

Sektor dalam kegiatan perekonomian masyarakat yaitu sektor moneter dan sektor riil, tidak dapat dipisahkan. Kedua sektor tersebut berinteraksi saling mempengaruhi satu dengan yang lain. Sektor riil tidak akan dapat bekerja dengan baik apabila sektor moneternya tidak bekerja dengan baik juga.

c. Agent of Services

Jasa-jasa yang ditawarkan bank ini erat kaitannya dengan kegiatan perekonomian masyarakat secara umum. Jasa-jasa bank ini antara lain dapat berupa jasa pengiriman uang, jasa penitipan barang berharga, jasa pemberian jaminan bank, dan jasa penyelesaian tagihan.

\section{Fungsi Pengawasan Bank}

Fungsi pokok bank adalah mengumpulkan dana dari masyarakat dan menyalurkannya kembali dana tersebut kepada masyarakat dalam bentuk kredit. Aktivitas pengumpulan dana dilakukan semata-mata atas dasar kepercayaan, artinya nasabah penyimpan dana merasa aman dan percaya bahwa bank akan mengembalikan dananya ketika telah jatuh tempo. Salah satu lembaga yang paling efektif dalam meningkatkan tabungan nasional adalah melalui kegiatan penghimpunan dana yang dilakukan oleh perbankan. Untuk itu bank perlu mendapat perlindungan melalui sistem pengawasan oleh otoritas agar benar-benar dapat menjaga kepercayaan yang diberikan masyarakat.

Pengawasan perbankan pada prinsipnya terbagi dalam dua jenis, yaitu macro economic supervision dan prudential supervision. Macro economic supervision adalah pengawasan dalam rangka mendorong bank-bank untuk ikut menunjang pertumbuhan ekonomi dan menjaga kestabilan moneter, prudential supervision adalah pengawasan yang mendorong bank secara individual tetap sehat serta mampu memelihara kepentingan secara baik. ${ }^{5}$ Tujuan dilakukannya pengawasan macro prudential supervision adalah mengarahkan dan mendorong bank serta mengawasi agar dapat berperan dalam berbagai program pencapaian sasaran ekonomi makro. Sedangkan tujuan prudential supervision adalah mengupayakan agar setiap bank secara individual sehat dan aman, serta seluruh industri perbankan sehat, sehingga kepercayaan masyarakat dapat terjaga.

\footnotetext{
${ }^{5}$ Zulkarnain Sitompul, Perlindungan Dana Nasabah : Suatu Gagasan Tentang Pendirian Lembaga Penjamin Simpanan di Indonesia, (Jakarta: Fakultas Hukum Universitas Indonesia, 2002 ), halaman 220-221.
}

\section{Tinjauan Umum Otoritas Jasa Keuangan}

Otoritas Jasa keuangan adalah lembaga yang menyelenggarakan fungsi pemerintah dalam rangka mengatur dan mengawasi kegiatan sektor jasa keuangan. ${ }^{6}$ setiap pihak dilarang campur tangan dalam pelaksanaan tugas dan wewenang Otoritas Jasa Keuangan. Maksudnya adalah bahwa untuk menjamin terselenggaranya pengaturan dan pengawasan sektor jasa keuangan yang optimal, Otoritas Jasa Keuangan harus dapat bekerja secara independen dalam membuat dan menerapkan tugas dan wewenangnya sebagaimana dimaksud dalam peraturan perundang-undangan di bidang jasa keuangan.

Mengenai kedudukan dari Otoritas Jasa Keuangan ini dapat dilihat dalam penjelasan Pasal 34 Undang-undang Nomor 3 Tahun 2004, yaitu Otoritas Jasa Keuangan bersifat independen dalam menjalankan tugas dan kedudukannya berada diluar pemerintah dan berkewajiban menyampaikan laporan kepada BPK dan DPR. Namun demikian dalam pelaksanaan tugas dan wewenangnya itu, Otoritas Jasa Keuangan perlu melakukan koordinasi dengan beberapa lembaga seperti Bank Indonesia, Lembaga Penjamin Simpanan, serta Menteri Keuangan bahkan Presiden. Pendirian Otoritas Jasa Keuangan memang baik, Pertama, meningkatkan dan memelihara kepercayaan publik di bidang jasa keuangan. Kedua. menegakkan peraturan perundang-undangan di bidang jasa keuangan. Ketiga, meningkatkan pemahaman publik mengenai bidang jasa keuangan. Keempat, melindungi kepentingan konsumen jasa keuangan. disamping itu, tujuan pembentukkan Otoritas Jasa Keuangan ini agar Bank Indonesia fokus kepada pengelolaan moneter dan tidak perlu mengurusi pengawasan bank karena bank itu merupakan sektor dalam perekonomian.

\section{METODE PENELITIAN}

\section{Metode Pendekatan}

Metode pendekatan yang dilakukan dalam penelitian ini adalah pendekatan yuridis normatif. Pendekatan yuridis normatif dilakukan dengan mempelajari dan mengkaji azas-azas hukum dan kaidah-kaidah atau norma-norma hukum positif yang berasal dari bahan-bahan kepustakaan yang ada, dari peraturan perundang-undangan serta ketentuan-ketentuan hukum yang berkaitan dengan kewenangan BI Dalam Melakukan Fungsi Pengawasan pada Lembaga Keuangan Bank Pasca Lahirnya Undang-undang Nomor 21 Tahun 2011 tentang Otoritas Jasa Keuangan.

\footnotetext{
${ }^{6}$ Pasal 3 Rancangan Undang-undang tentang Otoritas Jasa Keuangan
} 


\section{Spesifikasi Penelitian}

Penelitian ini dilakukan secara deskriptif analitis yaitu prosedur atau pemecahan masalah penelitian dilakukan dengan cara memaparkan objek yang diselidiki sebagaimana adanya berdasarkan fakta-fakta aktual pada saat sekarang yang tidak tebatas hanya sampai pada pengumpulan data tetapi meliputi analisis dan intepretasi tentang arti data tersebut. Hal itu dimaksudkan untuk memberikan gambaran sekaligus analisis mengenai kewenangan BI dalam melakukan fungsi pengawasa pada lembaga keuangan Bank pasca lahirnya Undang-undang Nomor 21 Tahun 2011 tentang Otoritas Jasa Keuangan.

\section{Teknik Pengumpulan data}

Data-data yang hendak dikumpulkan adalah data-data sekunder dari hukum positif, yang meliputi bahan-bahan hukum, baik bahan hukum primer, bahan hukum sekunder ${ }^{7}$

\section{Analisis Data}

Analisis data yang digunakan adalah analisa kualitatif, pada tahap ini data yang diperoleh disusun secara sistematis, melakukan kajian atau telaah terhadap hasil pengolahan data yang dibantu dengan teori-teori yang telah didapat sebelumnya dari peraturan-peraturan seperti Undang-undang Nomor 21 Tahun 2011 tentang Otoritas Jasa Keuangan dan kemudian membuat suatu kesimpulan terhadap hasil penelitian dengan pikiran sendiri dan bantuan teori yang telah dikuasai untuk selanjutnya dihasilkan suatu kejelasan dari masalah yang diteliti, dalam bentuk karya ilmiah berupa laporan penelitian.

\section{HASIL DAN PEMBAHASAN}

\section{KEWENANGAN BANK INDONESIA (BI) PASCA LAHIRNYA UNDANG-UNDANG NOMOR 21 TAHUN 2011 TENTANG OTORITAS JASA KEUANGAN}

\subsection{Tujuan dan Tugas BI}

Bank sentral adalah lembaga negara yang mempunyai wewenang untuk mengeluarkan alat pembayaran yang sah dari suatu negara, merumuskan dan melaksanakan kebijakan moneter, mengatur dan menjaga kelancaran sistem pembayaran, mengatur dan mengawasi perbankan, serta menjalankan fungsi sebagai lender of the last resort. ${ }^{8}$

\footnotetext{
${ }^{7}$ Ibid, hal 40.

${ }^{8}$ Penjelasan Pasal 4 ayat (1) Undang-undang Nomor 3 Tahun 2004 tentang Lembaga Penjamin Simpanan.
}

Undang-undang yang kini berlaku yang mengatur kedudukan Bank Indonesia sebagai bank sentral, yaitu Undang-undang Nomor 23 Tahun 1999 tentang BI serta undang-undang perubahannya, yaitu Undang-undang Nomor 3 Tahun 2004 tentang Perubahan atas Undang-undang Nomor 23 Tahun 1999 tentang Bank Indonesia. Undangundang tersebut merupakan peraturan pengganti dari Undang-undang Nomor 13 Tahun 1968 tentang bank sentral. Ketentuan Pasal 7 Undangundang Nomor 23 Tahun 1999 tentang BI sebagaimana yang telah diubah dengan Undang-undang Nomor 3 Tahun 2004 mengatur bahwa tujuan Bank Indonesia adalah mencapai dan memelihara kestabilan nilai rupiah. Dari tugas utama tersebut bila dilihat secara operasional, terdapat peran dan fungsi Bank Indonesia sebagai bank sentral. Peran dan fungsi BI sebagai bank sentral adalah :

1. BI sebagai badan pembuat kebijakan moneter. Dalam hal ini BI menetapkan sasaran-sasaran moneter dan melakukan pengendalian moneter, baik berdasarkan sistem perbankan konvensional maupun berdasarkan sistem syariah. Oleh sebab itu, BI melaksanakan fungsinya tersebut dengan menggunakan caracara yang diatur dalam Pasal 10 Undangundang Nomor 23 Tahun 1999 sebagaimana yang telah diubah dengan Undang-undang Nomor 3 Tahun 2004, yaitu :

a. Operasi pasar terbuka,

b. Penetapan tingkat diskonto,

c. Penetapan cadangan wajib minimum, dan

d. Pengaturan kredit atau pembiayaan.

2. BI sebagai pengontrol kredit kepada bankbank (credit control). Termasuk didalamnya bank yang berdasarkan prinsip syariah. Diatur dalam Pasal 11 Undang-undang Nomor 23 Tahun 1999 sebagaimana yang telah diubah dengan Undang-undang Nomor 3 Tahun 2004.

3. BI bertindak sebagai penerbit mata uang rupiah. BI merupakan satu-satunya lembaga yang berwenang untuk mengeluarkan dan mengedarkan uang rupiah dalam bentuk uang kertas dan logam. BI juga berwenang untuk menarik dan memusnahkan uang rupiah yang telah dikeluarkannya. Diatur dalam Pasal 20 jo Pasal 23 ayat (1) Undang-undang Nomor 23 Tahun 1999 sebagaimana yang telah diubah dengan Undang-undang Nomor 3 Tahun 2004.

4. BI sebagai pengatur dan pengawas bank. Oleh sebab itu, BI berwenang untuk menetapkan ketentuan-ketentuan perbankan yang memuat prinsip kehati-hatian.

9 Rina Hasiani Sinaga, Tinjauan Yuridis Independensi Bank Indonesia Sebagai Bank Sentral, Skripsi Sarjana, fakultas Hukum Universitas Indonesia Depok, halaman 66-68. 
Sehubungan dengan hal ini, BI mempunyai wewenang untuk :

a) Menetapkan peraturan-peraturan di bidang perbankan (Pasal 25 Undangundang Nomor 23 Tahun 1999 sebagaimana yang telah diubah dengan Undangundang Nomor 3 Tahun 2004),

b) Memberikan dan mencabut izin atas kelembagaan dan kegiatan usaha tertentu dari bank (Pasal 26 Undang-undang Nomor 23 Tahun 1999 sebagaimanan yang telah diubah dengan Undang-undang Nomor 3 tahun 2004),

c) Melaksanakan pengawasan bank (Pasal 27 Undang-undang Nomor 23 Tahun 1999 sebagaimanan yang telah diubah dengan Undang-undang Nomor 3 Tahun 2004), dan

d) Mengenakan sanksi terhadap bank sesuai dengan peraturan yang berlaku (Pasal 31 Undang-undang Nomor 23 Tahun 1999 sebagaimana yang telah diubah dengan Undang-undang Nomor 3 Tahun 2004.

5. BI bertindak sebagai lender of the lest resort, yaitu BI berfungsi sebagai pemberi pinjaman kepada bank dalam keadaan yang memaksa untuk menjaga likuiditas dari bank tersebut. Dalam hal ini BI melakukan penilaian terhadap suatu bank. Keadaan memaksa tersebut dapat berupa :

a) Hal-hal yang membahayakan kelangsungan usaha bank yang bersangkutan,

b) Hal-hal yang membahayakan sistem perbankan, dan

c) Terjadi kesulitan perbankan yang membahayakan perekonomian nasional.

6. BI sebagai bank negara (the banker of the state). BI bertindak sebagai bank dari dan untuk pemerintah indonesia. Dengan demikian, berdasarkan fungsinya tersebut, BI berwenang :

a) Sebagai pemegang kas pemerintah (Pasal 52 Undang-undang Nomor 23 Tahun 1999 sebagaimana yang telah diubah dengan Undang-undang Nomor 3 tahun 2004),

b) Menerima pinjaman luar negeri, menatausahakan serta menyelesaikan tagihan dan kewajiban keuangan pemerintah terhadap pihak luar negeri (Pasal 53 Undangundang Nomor 2 tahun 1999 sebagaimana yang telah diubah dengan Undang-undang nomor 3 tahun 2004), dan

c) Membantu pemerintah dalam penerbitan surat-surat utang negara (Pasal 55 ayat (3) Undang-undang Nomor 23 tahun 1999 sebagaimana yang telah diubah dengan Undang-undang Nomor 3 Tahun 2004).
1.2. Status dan Kedudukan Bank Indonesia sebagai Lembaga Negara yang Independen Pengaturan independensi BI telah ditetapkan dalam Undang-undang Nomor 23 Tahun 1999 tentang BI sebagaimana telah diubah dengan Undang-undang Nomor 3 Tahun 2004. Sesuai Undang-undang, BI adalah lembaga negara yang independen dalam melaksanakan tugas dan wewenangnya, bebas dari campur tangan pemerintah atau pihak lain. Tujuan BI difokuskan pada kestabilan nilai rupiah dengan tugas-tugas kebijakan moneter, sistem pembayaran dan perbankan. Demikian pula, kewenangan dan akuntabilitas BI telah diatur secara jelas dalam undang-undang.

Independensi kelembagaan ini bukan berarti bahwa BI adalah suatu negara karena independensi dimaksud hanya terbatas pada tugas dan wewenang yang ditetapkan dalam undang-undang. BI tetap tunduk pada segala ketentuan hukum di Indonesia atas hal-hal yang bukan merupakan cakupan tugas dan wewenang yang diatur dalam undang-undang BI. ${ }^{10}$

Pengawasan yang dilaksanakan BI terhadap bank dapat berupa :

1. pengawasan langsung/pemeriksaan, yaitu berbentuk pemeriksaan yang disusul dengan tindakan-tindakan perbaikan, dalam pengawasan langsung, otoritas pengawasan bank ingin meyakini kondisi bank secara langsung berdasarkan data dan dokumen yang dipelihara oleh bank, sekaligus menguji kebenaran dan konsistensi pembuatan laporan yang disampaikan kepada otoritas pengawasan bank. $^{11}$

2. Pengawasan tidak langsung, yaitu suatu bentuk pengawasan dini melalui penelitian analitis, dan evaluasi laporan bank.

Dalam pengawasan tidak langsung, otoritas moneter mengawasi kondisi bank secara individual, kelompok, maupun keseluruhan dengan menelaah berbagai laporan yang disampaikan oleh perbankan.

Pembentukkan lembaga baru dalam bidang pengawasan tentu akan berdampak bagi Bank Indonesia dalam mengemban tugas untuk mengatur dan mengawasi bank, sesuai dengan ketentuan Pasal 24 Undang-undang Nomor 23

\footnotetext{
${ }^{10}$ Sugiyono, F.X dan Ascarya, Bank Indonesia Bank Sentral Republik Indonesia Sebuah Pengantar : Kelembagaan Bank Indonesia. (PusatPendidikan dan Studi Kebanksentralan Bank Indonesia : Jakarta), 2004, halaman 43-44

11 Permadi Gandapradja, Dasar dan Prinsip Pengawasan Bank (PT Gramedia Pustaka Utama : Jakarta), 2004, halaman 14.
} 
Tahun 1999 tentang Bank Indonesia sebagaimana yang telah diubah dengan UU Nomor 3 Tahun 2004, berwenang untuk menetapkan peraturan, memberikan dan mencabut izin atas kelembagaan dan kegiatan usaha tertentu dari bank, melaksanakan pengawasan bank, dan mengenakan sanksi terhadap bank sesuai dengan ketentuan perundang-undangan.

Dalam melakukan tugasnya, OJK melakukan koordinasi dan kerja sama dengan BI sebagai bank sentral yang akan diatur dalam Undang-undang dan OJK. OJK mengeluarkan ketentuan yang berkaitan dengan pelaksanaan tugas pengawasan bank dan koordinasi dengan BI dan meminta penjelasan dari BI keterangan dan data makro yang diperluan (penjelasan Pasal 34 Undang-undang Nomor 3 Tahun 2004).

Tugas dan wewenang OJK dalam hal pengawasan perbankan hanya berkaitan dengan aspek micoprudential seperti kelembagaan, kegiatan usaha, dan penilaian tingkat kesehatan. Sementara itu aspek macro prudential berkaitan dengan kebijakan moneter dan sistem pembayaran seperti ketentuan tentang Giro Wajib Minimum (GWM), ketentuan devisa, Operasi Pasar Terbuka (OPT), dan laporan-laporan serta pemeriksaan yang terkait dengan pelaksanaan tugas di bidang moneter dan sistem pembayaran merupakan kewenangan dari otoritas moneter BI.

Tugas micro prudential banking regulation yang menjadi kewenangan membuat dan menetapkan pengaturan yang berkaitan dengan pelaksanaan pembinaan dan pengawasan bank serta ketentuan kehati-hatian yang berkaitan dengan individual bank dalam rangka menjaga bank tetap aman dan sehat. ${ }^{12}$

Seperti yang telah disebutkan sebelumnya, yang dimaksud dengan ketentuan kehati-hatian yang dikenal sebagai micro prudential banking regulation meliputi : ${ }^{13}$

1) Pengaturan kelembagaan, antara lain mengenai perizinan untuk pendirian bank, pembukaan kantor bank dalam negeri, kepemilikan dan kepengurusan, merger, konsolidasi, dan akuisisi bank,

2) Pengaturan kegiatan usaha dan pengelolaan bank, antara lain mengenai sumber dana, penyediaan dana, aktivitas di bidang jasa,

3) Pengaturan pembinaan dan pengawasan bank, antara lain mengenai penilaian tingkat

12 Sila Saktiana, Analisis Yuridis Mengenai Dampak Pembentukkan Otoritas Jasa Keuangan Terhadap Pengawasan Perbankan Syariah (Skripsi Sarjana,Fakultas Hukum Universitas Indonesia, Depok), 2004, halaman 77-78.

${ }^{13} \mathrm{Ibid}$, halaman 78. kesehatan bank, dan

4) Pengaturan likuidasi bank, antara lain mengenai pencabutan izin usaha, pembubaran, dan likuidasi bank.

Di dalam Penjelasan Pasal 69 ayat (1) huruf (a) UU OJK menegaskan bahwa tugas BI dalam mengatur dan mengawasi bank yang dialihkan ke OJK adalah tugas pengaturan dan pengawasan yang berkaitan dengan microprudential. Sedangkan BI tetap memiliki tugas pengaturan perbankan terkait macroprudential. Berkaitan dengan hal ini, jelas bahwa tugas pengaturan perbankan tidak sepenuhnya dilaksanakan secara independen oleh OJK karena pengaturan microprudential dan macroprudenti akan sangat berkaitan. Dalam pengaturan tersebut kita juga dapat melihat bahwa OJK masih memiliki hubungan khusus dengan BI terutama dalam pengaturan dan pengawasan perbankan, bagaimanapun BI sebagai bank sentral, dimana sebelum diterbitkannya UU OJK dan pengalihan pada akhir Desember 2013, mengemban dan melaksanakan tugas pengaturan dan pengawasan bank dan memiliki pengalaman lebih lama dalam mengatur dan mengawasi perbankan sehingga masukan pengaturan yang disampaikan oleh BI akan memiliki pengaruh yang besar dalam pengaturan yang dilakukan oleh OJK.

Selain itu hubungan khusus antara OJK dengan BI lainnya dapat dilihat dari Pasal 41 ayat 2 UU OJK, dimana OJK menginformasikan kepada BI untuk melakukan langkah-langkah yang diperlukan terkait dengan kesulitan likuiditas atau memburuknya kesehatan pada bank. Yang dimaksud dengan langkah-langkah tersebut yatu pemberian fasilitas pembiayaan jangka pendek dalam menjalankan fungsi BI sebagai lender of resort. Berdasarkan hal tersebut, maka bila bank mengalami kesulitan likuiditas atau memburuknya kesehatan bank, maka BI dapat memberikan kredit kepada bank dengan jaminan dan mudah dicairkan. Dengan demikian, tidak dipungkiri bahwa keberadaan BI sebagai lender of resort masih sangat diperlukan di sektor perbankan dan OJK nantinya masih akan bergantung kepada BI khususnya yang terkait dengan penyelamatan bank.

\section{INDEPENDENSI OTORITAS JASA KEUANGAN (OJK) DALAM PENGAWASAN PERBANKAN DI INDONESIA}

Setelah adanya Undang-undang Nomor 21 Tahun 2011 tentang OJK, terhitung sejak 31 Desember 2013, dan dengan ditandatanganinya BAST antara BI dan OJK, maka tugas pengaturan dan pengawasan perbankan yang semula berada 
pada BI sebagai bank sentral di negara kita dialihkan kepada OJK. Sejak tanggal 31 Desember 2013 tersebut, pengawasan terhadap individual bank (microprudential) dilakukan oleh OJK. Namun pengawasan terhadap macroprudential tetap dilakukan oleh BI, berkoordinasi dengan OJK. ${ }^{14}$ Pembentukkan undang-undang OJK ini dimaksudkan untuk memisahkan fungsi pengawasan perbankan dari bank sentral ke sebuah badan atau lembaga yang independen di luar bank sentral. Dasar hukum pemisahan fungsi pengawasan tersebut, yaitu Pasal 34 Undangundang Nomor 3 Tahun 2004 tentang Perubahan atas Undang-undang Nomor 23 Tahun 1999 tentang BI yang menyatakan :

(1) Tugas mengawasi bank akan dilakukan oleh lembaga pengawasan sektor jasa keuangan yang independen, dan dibentuk dengan undang-undang,

(2) Pembentukkan lembaga pengawasan sebagaimana dimaksud pada ayat (1), akan dilaksanakan selambat-lambatnya 31 Desember 2010.

Pengawasan yang dilakukan, yaitu terhadap bank dan perusahaan-perusahaan sektor jasa keuangan lainnya yang meliputi asuransi, dana pensiun,sekuritas,modal ventura dan perusahaan pembiayaan, serta badan-badan lain yang menyelenggarakan pengelolaan dana masyarakat. Lembaga ini bersifat independen dalam menjalankan tugasnya dan kedudukannya berada di luar pemerintah dan berkewajiban menyampaikan laporan kepada Badan Pemeriksa Keuangan dan Dewan Perwakilan Rakyat.

Keindependenan OJK berkaitan dengan beberapa hal, Pertama, independen yang berkait dengan pemberhentian anggota lembaga yang hanya dapat dilaukan berdasarkan sebab-sebab yang diatur dalam undang-undang pembentukkan lembaga yang bersangkutan, tidak sebagaimana lazimnya adminstrative agencies yang dapat sewaktu-waktu oleh Presiden karena jelas merupakan bagian dari eksekutif.

Kedua, selain masalah pemberhentian yang terbebas dari intervensi Presiden, sifat independen juga tercermin dari :

1. Kepemimpinan lembaga yang bersifat kolektif, bukan hanya satu orang pimpinan. Kepemimpinan kolegial ini berguna untuk proses internal dalam pengambilan keputusankeputusan, khususnya menghindari kemungkinan politisasi keputusan sebagai akibat proses pemilihan keanggotaannya,

\footnotetext{
${ }^{14}$ Bank Indonesia, "Alihkan Fungsi Pengaturan dan Pengawasan Bank Kepada Otoritas Jasa Keuangan" dalam Siaran Pes Bersama Bank Indonesia Nomor 15/56/Dkom.
}

2. Kepemimpinan tidak dikuasai atau tidak mayoritas berasal dari partai politik tertentu, dan

3. Masa jabatan para pemimpin lembaga tidak habis secara bersamaan, tetapi bergantian (staggered terms). ${ }^{15}$

Azas independensi secara lebih tegas dituangkan dalam Penjelasan Umum UU OJK yang menyatakan bahwa OJK melaksanakan tugas dan wewenangnya berlandaskan antara lain asas independensi yaitu independen dalam pengambilan keputusan dan pelaksanaan fungsi, tugas dan wewenang OJK dengan tetap sesuai peraturan perundang-undangan yang berlaku. ${ }^{16}$

Sebagai lembaga yang didirikan dan bersifat independen, tentunya OJK mempunyai peran yang sangat strategis dalam melakukan pengawasan terhadap seluruh lembaga keuangan yang berada di wilayah Indonesia termasuk di dalamnya industri perbankan. Pentingnya independensi bagi otoritas pengawas jasa keuangan paling tidak karena dua hal. Pertama, hampir semua krisis keuangan yang terjadi pada tahun 1990 an diakibatkan oleh pengaruh politik. Lemah dan tidak efektifnya regulasi seringkali disebabkan campur tangan politik. Kedua, dialihkannya kewenangan pengawasan dari bank sentral. Bank sentral selama ini telah mendapat independen sehingga dengan dialihkannya pengawasan dari bank sentral, isu independensi muncul kembali. Di samping itu, pendirian lembaga pengawas yang super power menimbulkan kekhawatiran tentang kewenangan besar yang dimilikinya. ${ }^{17}$

Otoritas pengawas lembaga jasa keuangan membutuhkan independensi, baik dari pemerintah maupun dari industri yang diawasi. Dengan begitu tujuan OJK untuk memastikan keseluruhan kegiatan di dalam sektor jasa keuangan terselenggara secara teratur, adil, transparan dan akuntabel dapat tercapai. Disamping itu, OJK juga diharapkan mampu mewujudkan sistem keuangan yang tumbuh secara berkelanjutan dan stabil serta mampu melindungi kepentingan konsumen dan masyarakat. Pasal 2 UU OJK menetapkan bahwa OJK adalah lembaga yang independen dalam melaksanakan tugas dan wewenangnya serta bebas dari campur tangan Untuk menentukan independensi suatu lembaga pengawas, dapat digunakan empat dimensi yang menjadi alat ukur

\footnotetext{
15 Zainal Arifin Mochtar dan Iwan Satriawan, Jurnal Konstitusi,Volume 6,Nomor 3,September 2009, halaman 152.

${ }^{16}$ Penjelasan Umum Paragraf 14 UU OJK

17 Zulkarnain Sitompul,Problematika Perbankan (Books Terrace \& Library,Bandung,2005), hal 224.
} 
independensi, yaitu regulasi, supervisi,insttusi dan anggaran. Independensi regulasi dan supervisi merupakan independensi inti. Independensi institusi dan anggaran dibutuhkan untuk mendukung pelaksanaan fungsi regulasi dan supervisi tersebut. Independensi regulasi dan supervisi sulit untuk dicapai tanpa pengaturan yang jelas tentang independensi institusi dan anggaran. Independensi regulasi dimaksudkan sebagai kemampuan dari lembaga pengawas memperoleh suatu tingkatan otonomi dalam menetapkan peraturan teknis yang mengatur industri keuangan sebaiknya hanya mengatur hal-hal prinsip sehingga lembaga pengawas dapat leluasa menerbitkan dan mengamandemen regulasi teknis tanpa perlu melibatkan atau melalui proses politik (legislasi).

Pendekatan lain untuk mengukur tingkat independensi Otoritas Jasa Keuangan dengan melihat dua hal. Pertama, kejelasan tujuan, yakni :

1) tujuan yang ditetapkan secara jelas dapat membantu pengurus membuat keputusan tentang alokasi sumber daya dan dalam meenttukan respons kebijakan yang terdapat dalam situasi tertentu,

2) tujuan adanya pengaturan tentang akuntabilitas untuk keputusan dan respons kebijakan. Pasal 4 Undang-undang Otoritas Jasa Keuangan menetapkan bahwa Otoritas Jasa Keuangan dibentuk dengan tujuan agar keseluruhan kegiatan di dalam sektor jasa keuangan :

a. terselenggara secara teratur, adil, transparan, dan akuntabel,

b. mampu mewujudkan sistem keuangan yang tumbuh secara bekelanjutan dan stabil, dan

c. mampu melindungi kepentingan konsumen dan masyarakat.

Kedua,independensi, akuntabilitas, integritas dan sumber daya yang memadai. Lembaga independen harus mampu memformulasikan kebijakan atas dasar strategi jangka panjang dan dapat mengambil keputusan yang kredibel. Independensi dapat diperoleh dengan adanya ketentuan yang mengatur tentang pemberhentian pengurus, otonomi anggaran, dan kemampuan mengalokasikan sumber daya berdasarkan kebijakan internal lembaga.

\section{SIMPULAN DAN SARAN}

\section{SIMPULAN}

1. Bank Indonesia dalam mengemban tugas untuk mengatur dan mengawasi bank, sesuai dengan ketentuan Pasal 24 Undang-undang Nomor 23 Tahun 1999 tentang BI sebagaimana telah diubah dengan Undang-undang Nomor 3 Tahun 2004, berwenang untuk menetapkan peraturan, memberikan, dan mencabut izin atas kelembagaan dan kegiatan usaha tertentu dari bank, melaksanakan pengawasan bank, dan mengenakan sanksi terhadap bank sesuai dengan ketentuan perundang-undangan. Mengacu pada ketentuan tersebut jelas bahwa BI memiliki kewenangan, tanggung jawab dan kewajiban secara utuh untuk melakukan pembinaan dan pengawasan terhadap bank dengan menempuh upaya-upaya baik yang bersifat preventif maupun represif. Pengawasan yang dapat dilaksanakan BI terhadap bank dapat berupa pengawasan langsung yang berbentuk pemeriksaan dengan tindakan-tindakan perbaikan, dan pengawasan tidak langsung melalui penelitian analitis dan evaluasi laporan bank. Setelah terbentuknya Undangundang OJK Nomor 21 Tahun 2011, pengawasan perbankan tidak lagi berada di tangan Bank Indonesia. BI sebagai bank sentral meskipun telah terbentuk lembaga pengawasan tersebut, perannya tidak dikesampingkan dalam pengawasan bank karena lembaga tersebut (OJK) tetap harus mempunyai hubungan koordinasi yang baik dengan BI, diantaranya menyangkut keterangan nasabah dan data makro perbankan yang ada.

2. Azas independensi secara lebih tegas dituangkan dalam penjelasan umum UU OJK yang menyatakan bahwa OJK melaksanakan tugas dan wewenangnya berlandaskan azas independen dalam pengambilan keputusan dan pelaksanaan fungsi, tugas dan wewenang OJK dengan tetap sesuai peraturan perundangundangan yang berlaku. Pentingnya independensi bagi otoritas pengawas jasa keuangan dikarenakan dua hal. Pertama, hampir semua krisis keuangan yang terjadi pada tahun 1990 an diakibatkan oleh pengaruh politik. Lemah dan tidak efektifnya regulasi seringkali disebabkan campur tangan politik. Kedua, dialihkannya kewenangan pengawasan dari bank sentral. Pasal 2 UU OJK menetapkan bahwa OJK adalah lembaga yang independen dalam melaksanakan tugas dan wewenangnya serta bebas dari campur tangan pihak lain.

\section{Saran}

1. Sebagai lembaga yang menghimpun dana dari masyarakat dan menyalurkannya kembali kepada masyarakat dalam bentuk kredit, lembaga perbankan diwajibkan memelihara tingkat kesehatannya. Oleh karenanya untuk menjaga kesehatan tersebut, sangat diperlukan peran lembaga pengawas yang mengawasi 
segala bentuk kegiatan operasional yang dilakukan oleh perbankan agar tetap dalam kondisi yang diinginkan.

2. Dengan dialihkannya fungsi pengawasan lembaga keuangan bank dan non bank dari BI ke lembaga independen OJK harus dapat berperan aktif dalam pengawasan di dunia perbankan dari sisi microprudential. Lembaga baru ini diharapkan dapat menciptakan suasana yang kondusif pada industri keuangan perbankan sehingga bank dapat selalu memelihara tingkat kesehatannya dengan sifat ke-independenan yang dimiliki.

\section{DAFTAR PUSTAKA}

\section{BUKU/LITERATUR}

Abdurahman, Ensiklopedi Ekonomi Keuangan dan Perbankan Inggris Indonesia, Jakarta: Pradnya Paramita, 1980.

Faisah, Sanapiah, Penelitian Kualitatif: Dasardasar dan Aplikasi, Malang: YA3, 1990.

Fuady, Munir, Hukum. Perbankan Modern: Buku Kesatu, Bandung: PT. Citra Aditya. Bakti, 2003.

Hadad, Muliaman D, Perlindungan dan Pemberdayaan Nasabah Bank Dalam Arsitektur Perbankan Indonesia, Diskusi Badan Perlindungan Konsumen Nasional, Jakarta, 16 Juni 2006

Kansil, C.S.T, Pokok-Pokok Hukum Perbankan Di Indonesia, Jakarta: Pradnya Paramita, 1982.

Lembaga Kajian Hukum Ekonomi, Sejarah dan Perkembangan. Perbankan. Di Indonesia, Jakarta: Bank Indonesia, 1990.

Lukman Dendawijaya, Manajemen Perbankan, Jakarta: Penerbit Ghalia Indonesia, 2003.

Sunggono, Bambang, Metodologi Penelitian Hukum (Suatu Pengantar), Jakarta: PT. Raja Grafindo Persada, 2003.

Syamsi, Deyuzar ,Prospek Bisnis Tanpa Uang Tunai, (Bank \& Manajemen, No.53 Maret/April 2000, PT. Bank Negara Indonesia Tbk).

S. Gazali, Djoni dan Rachmadi Usman, Hukum Perbankan.Cet.Ke 1, Jakarta: PT.Sinar Grafika
Soemitro, Ronny Hanitijo, Metodologi Penelitian hukum dan Jurimetri, Jakarta: Ghalia Indonesia, 1998.

Simorangkir, O.P, Pengantar Lembaga. Keuangan, Jakarta; Penerbit Ghalia Indonesia, 2004.

Syahdeini, Sutan Remi, Kebebasan Berkontrak dan Perlindungan Yang Seimbang Bagi Para Pihak Dalam Perjanjian Kredit Bank di Indonesia, Jakarta: Lembaga Pengembangan Perbankan Indonesia, 1993.

Soekanto, Soerjono dan Sri Mamudji, Penelitian Hukum Normatif, Suatu. Tinjauan Singkat, Jakarta: Rajawali Press, 1990.

Sembiring, Hukum Perbankan, Bandung : Mandar Maju, 2012

Suyitno,Thomas ,Kelembagaan Perbankan, Jakarta: Gramedia, 1990

Sutedi, Andrian, Aspek Hukum Otoritas Jasa Keuangan, Jakarta: Raih Asa Sukses,2014

Sautma Hotma Bako, Ronny, Hubungan Bank dan Nasabah Terhadap Produk Tabungan dan Deposito (Suatu Tinauan Hukum Terhadap Perlindungan Deposal Di Indonesia), Bandung : Citra Aditya Bakti, 2005

Usman , Rachmadi,AspekAspek Hukum Perbankan Di Indonesia, Jakarta: PT. Gramedia Pustaka Utama, 2001.

W.J.S., Poerwadarminta, Kamus Umum Bahasa Indonesia, Jakarta: Balai Pustaka, 1976

Zulkarnain, Sitompul, Problematika Perbankan. Bandung: Books Terrace \& Library, 2005.

\section{PERATURAN PERUNDANG-UNDANGAN}

UU Nomor 7 Tahun 1992 jo UU Nomor 10 Tahun 1998 tentang Perbankan

UU Nomor 21 Tahun 2011 tentang Otoritas Jasa Keuangan

Peraturan BI No 7/7/PBI/2005 tentang Penyelesaian Pengaduan Nasabah

Peraturan BI No 8/5/PBI/2006 tentang Mediasi Perbankan 